УДК 378.147:61(071.1)

DOI: 10.37026/2520-6427-2019-100-4-134-137
Світлана БУХАЛЬСЬКА,

кандидат педагогічних наук, викладач-методист, заступник директора з виховної роботи КЗВО «Рівненська медична академія» Рівненської обласної ради

Галина ГОЛОБОШ, стариий викладач КЗВО «Рівненська медична академія» Рівненської обласної ради

\title{
ФОРМУВАННЯ ТОЛЕРАНТНОСТІ СТУДЕНТІВ У ВИХОВНОМУ ПРОСТОРІ МЕДИЧНИХ ЗАКЛАДІВ ВИЩОЇ ОСВІТИ
}

У статті актуалізовано значення виховання складного $i$ багатогранного процесу формування особистості, забезпечення педагогічних умов для ії соиіального, фізичного, психологічного, професійного розвитку. Виокремлено дефініцію «виховний простір» як педагогічну умову формування толерантності студентів медичних закладів вищої освіти. Здійснено аналіз змісту поняття «толерантність»; визначено типи толерантності, які властиві медичним працівникам; представлено інтерактивну програму формування толерантності студентів-медиків.

Ключові слова: виховний простір, толерантність, типи толерантності, студент, медичні заклади вищої освіти, інтерактивна програма.

В статье актуализировано значение воспитания - сложного и многогранного прочесса формирования личности, обеспечение педагогических условий для её социального, физического, психологического, профессионального развития. Выделено дефиницию «воспитательное пространство» как педагогическое условие формирования толерантности студентов медицинских учебных заведений. Проанализировано содержание понятия «толерантность»; определено типь толерантности, свойственные медицинским работникам; представлено интерактивную программу формирования толерантности студентов-медиков.

Ключевые слова: воспитательное пространство, толерантность, типы толерантности, студент, медицинское учебное заведение, интерактивная программа.

The importance of education, a complex and multifaceted process of personality formation, providing pedagogical conditions for its social, physical, psychological, professional development, is actualized in the article. The definition of «educational space» as a pedagogical condition of forming tolerance of medical institutions students of higher education is singled out. It is stated that the educational space covers the educational territories where the educational influence on the individual formation occurs (educational classrooms, medical-preventive institutions, pharmacies, natural objects, historical monuments, art institutions). Educational space provides conditions for actualization and motivation of forming tolerance of medical education recipients; introduction of a complex of effective educational interactive technologies into the educational process of higher education institutions.

The analysis of the content of the concept «tolerance» as a moral and ethical category, the main principles of which are equality, mutual respect, goodwill, tolerant attitude towards all members of society.

It is stated that the tolerance of the medical worker is manifested as a medical and deontological characteristic of the specialist, which represents tolerance, tact, sincerity, charity, ability to compromise, humane approach to fulfilling professional duties. The types of tolerance that are inherent in medical professionals are identified: ethnic, political, gender, religious, interclass, age, sexually oriented, marginal, medical and deontological.

The effectiveness of interactive education technologies is that the educational process takes place under the conditions of constant, active interaction, the participants of which are equal equivalent subjects.

Our developed tolerance formation program covers information, discussion, problem-situation, expressive, training forms and methods of education.

Key words: educational space, tolerance, types of tolerance, student, medical institutions of higher education, interactive program.

Постановка проблеми. На сучасному етапі утвердження української держави потреба у висококваліфікованих фахівцях медичної галузі передбачає реалізацію гуманістичної парадигми виховної діяльності в освітньому процесі медичних закладів вищої освіти (ЗВО). У чинному Законі України «Про вищу освіту» актуалізовано проблему формування особистості шляхом виховання, утвердження в учасників освітнього процесу моральних цінностей, соціальної активності, громадянської позиції та відповідальності, здорового способу життя, вміння вільно мислити та самоорганізовуватися в сучасних умовах [5].

У системі медичної освіти передбачено гуманістичне спрямування виховання на основі глибокого взаєморозуміння та взаємоповаги всіх учасників освітнього процесу; толерантності; здатності співпереживати, 
відчувати і розуміти інших людей. Керуючись засадами педагогіки толерантності, вважаємо, що саме виховний простір як педагогічна умова формування толерантності забезпечує передачу досвіду позитивної соціальної взаємодії та досвіду людства загалом; $€$ зоною комфорту організації життєдіяльності особистості в соціумі та забезпечує успішну реалізацію здобувача освіти в колективі; розвиває моральне розуміння, співпереживання, здатність помірковано оцінювати вчинки інших.

У контексті нашого дослідження під толерантністю розуміємо одну 3 ціннісних характеристик здобувачів медичної освіти, яка набуває все більшого визнання в сучасному світі, зокрема в освітньому середовищі; впровадження ефективних виховних технологій формування толерантної особистості в освітній процес медичних ЗВО.

Аналіз наукових досліджень та публікацій. Від античних часів і до сьогодення феномен толерантності $\epsilon$ предметом досліджень у різноманітних галузях науки, зокрема філософії, соціології, літературі, педагогіці, психології, медицині тощо.

Античні філософи під толерантністю розуміли терпимість як ключову умову формування особистості. Арістотель (384 р. до н. е. - 322 р. до н. е.) у своїх працях описував душевний стан людини, що дає змогу «однаково поводитися 3 незнайомими та знайомими, близькими та сторонніми» [1, с. 138]. Актуальними на сьогодні $є$ настанови філософа: «Кращим варто вважати не того, хто здійснює доброчинності по відношенню до себе, а того, хто чинить так по відношенню до інших, а це - важка справа» [1, с. 85].

Уперше Луцій Анней Сенека (4 до н. е. -65 н. е.) серед морально-етичних цінностей виокремив толерантність (у латинському оригіналі - tolerantia) як особистісну якість людської душі, зокрема «справедливість і відвага, і терпеливість, і розумність, і скромність, і витриманість, і терпимість, і людськість як іiі найвище благо» [8, с. 239].

Фундаментальними у трактуванні значимості толерантності для православного християнства $є$ «Повчання Володимира Мономаха»: «Всєго же паче убогих не забывайте, но єлико могуще по силЂ кормите, и придайте сиротЂ, и вдовицю оправдите сами, а не вдавайте сильным погубити человЂка. Ни права, ни крива не убивайте, ни повелЂвайте убити єго: аще будеть повиненъ смерти, а душа не погубляйте никакоя же хрестьяны...» [2, с. 290].

Зміст толерантності як загальнолюдської цінності розкрито в гуманістичних ідеях українських філософів, літераторів, педагогів (Григорія Сковороди, Тараса Шевченка, Лесі Українки, Івана Франка, Бориса Грінченка, Василя Сухомлинського, Василя Симоненка та ін.), про що свідчать авторські вислови, які стали афоризмами.

Заслуговують на увагу напрацювання науковців сучасної педагогічної науки: Я. А. Берегового - із педагогіки толерантності; О. А. Гриви - вивчення соціально-педагогічних основ формування толерантності в дітей і молоді в умовах полікультурного середовища; О. В. Волошиної - дослідження педагогічних умов виховання толерантності в підлітків старшого віку в позакласній роботі; Н. М. Стеценко - виховання толерантності у студентів на основі міжкультурного діалогу; Л. Ф. Лозинської - визначення показників толерантності особистості майбутнього лікаря; Л. В. Черезової - актуалізація виховного простору в реалізації заходів із формування культури професій- ного спілкування. Водночас формування толерантності здобувачів медичної освіти в умовах виховного простору недостатньо вивчена в педагогічній теорії та практиці.

Мета статті полягає в обгрунтуванні змісту толерантності студентів медичних ЗВО; визначенні ролі виховного простору як педагогічної умови формування толерантності майбутніх медичних працівників.

Виклад основного матеріалу. Керуючись визначенням «толерантність - це терпимість до чиїхось поглядів, поведінки» [9, с. 700], вважаємо, що означена дефініція є морально-етичною категорією, основним принципом якої є свідоме підпорядкування особистих інтересів, емоцій, ставлень потребам людей.

У Декларації принципів толерантності (стаття 1) толерантність трактується як «повага, схвалення i правильне розуміння багатого різноманіття культур нашого світу, наших форм самовираження і способів виявів людської індивідуальності...; це гармонія в різноманітті; це чеснота, яка робить можливим досягнення миру і сприяє заміні культури війни культурою миру...». Ключовими принципами толерантності виокремлено:

- рівність між представниками різних народів незалежно від їх статі, раси, національності, релігії чи приналежності до будь-якої іншої групи;

- взаємну повагу, доброзичливість, терпиме ставлення всіх членів суспільства до представників інших соціальних, культурних, релігійних груп;

- відмову від насилля;

- рівні можливості для участі в політичному житті всіх членів суспільства;

- гарантоване законом збереження і розвиток культури та мов національних меншин;

- можливість дотримуватися традицій усіх культур, представлених у суспільстві;

- свободу віросповідання;

- співпрацю і солідарність у вирішенні спільних проблем [3, с. 175-180].

Слід розрізняти зміст поняття «толерантність» у медицині, під яким розуміють ступінь, до якого можна вводити або споживати ліки, не викликаючи при цьому в пацієнтів шкідливих побічних ефектів. У фармакології толерантність ототожнюють із синдромом звикання (резистентністю), що описує зниження реакції організму на лікарський засіб унаслідок його повторного використання. Водночас категорія «толерантність» медичного працівника відтворює виконання його професійних обов'язків. Нетерпимість, байдужість, формалізм медичних працівників можуть вартувати здоров'я та життя хворої людини. Тому формування толерантності у здобувачів медичної освіти шляхом виховання $є$ необхідним у процесі підготовки компетентних фахівців. Підтвердженням означеної думки є вислів Джона Локка, англійського філософа і педагога, про те, що виховання є ключовою необхідністю для створення людини нового суспільства, зокрема формування таких ціннісних орієнтирів, як справедливість, толерантність, уважливість, щедрість, мужність [7].

Якщо створення толерантного середовища в суспільстві передбачає профілактику тероризму, екстремізму, агресії та насильства, то в системі освіти - сприяє гуманізації освітнього процесу iз упровадженням ідей педагогіки толерантності. На нашу думку, саме в межах виховного простору відбувається набуття знань про толерантність як особистісну якість та вмінь визначати межі толерантності 
й дотримуватися їх у спілкуванні і ставленні до інших; формування навичок позитивної комунікації; виховання терпимості та співчуття.

Дослідниця дефініції «виховний простір» М. В. Черезова вважає, що у процесі створення виховного простору як педагогічної умови слід враховувати такі фактори: суб'єктивні (особистісні характеристики учасників освітнього процесу (характер, емоції, здібності, мотивація)) та об'єктивні (форми і методи організації освітнього процесу, інтеграційні характеристики: системність, послідовність, логічність). Об'єктивні та суб'єктивні фактори перебувають у постійному взаємозв'язку та взаємно впливають одні на інших [10, с. 39].

Узагальнено простір визначають як частину середовища за наявності сумісної діяльності його компонентів, їх співіснування. Тому не варто виховний простір обмежувати в певній площині. Виховний простір охоплює освітні території, де відбувається виховний вплив, наприклад: навчальні аудиторії, спортивні зали, мистецькі заклади, природні об'єкти (гірські масиви, водні артерії, парки, бальнеологічні комплекси), лікувально-профілактичні, аптечні та реабілітаційні установи тощо. Головною характеристикою виховного простору студентського колективу ЗВО є спільність діяльності, цілей і результатів, які відображають специфіку фахової підготовки.

Таким чином, виховний простір забезпечує умови для актуалізації та мотивації формування толерантності здобувачів медичної освіти; для впровадження в освітній процес ЗВО комплексу ефективних виховних технологій, зокрема інтерактивної програми формування толерантності.

Наголосимо, що виховання - це складний і багатогранний процес формування особистості, забезпечення педагогічних умов для іiі соціального, фізичного, психологічного та професійного розвитку. Важливим в організації освітнього процесу медичних 3 ВО є виховання особистості студента, набуття ним соціального досвіду, духовних надбань українського народу; формування в нього толерантності, морально-етичної, правової, валеологічної культури, навичок здорового способу життя; набуття й розвиток загальнолюдських норм, цінностей, правил та ідеалів поведінки у професійній діяльності.

Варто зауважити, що в педагогічній науці під формуванням розуміють процес становлення людини як соціальної істоти під впливом різноманітних чинників (національних, економічних, релігійних, соціальних, психологічних, виховних тощо). Формування передбачає певний рівень становлення людської особистості.

Актуалізація та мотивація формування толерантності зумовлена взаємодією медичних працівників із людьми та групами людей, котрі незалежно від їхньої національної, соціальної, релігійної належності, поглядів, стилю мислення і поведінки потребують медичної допомоги. Тому вважаємо за необхідне звернути увагу на формування таких типів толерантності в студентів медичних 3ВО: міжначіональної та політичнӧ̈ - неупередженому ставленні до представників різних націй, політичних партій тощо; гендерноі - до осіб іншої статі; релігійної- терпимому ставленні до прихильників різних релігійних конфесій; міжкласової - рівноцінному відношенні до представників різних майнових статків; вікової - поваги до осіб похилого віку; сексуально зорієнтованої - неупередженості стосовно осіб із нетрадиційною сексуаль- ною орієнтацією; маргінальної - терпимому ставленні до безхатченків, жебраків, наркоманів, алкоголіків, ув'язнених тощо; медико-деонтологічної- професійної та морально-етичної терпимості до хворих, інвалідів, фізично неповноцінних, осіб із порушеннями розвитку.

Наукову цінність для нашого дослідження мають напрацювання М. М. Філоненко, котра виділяє комплекс особистісних якостей, які мають бути в лікаря, це зокрема: морально-етичні (чесність, порядність, обов'язковість, відповідальність, інтелігентність, людяність, доброта, надійність, принциповість, безкорисливість, уміння тримати слово); комунікативні (особиста привабливість, увічливість, повага до оточення, готовність допомогти, авторитет, тактовність, уважність, спостережливість, уміння бути хорошим співрозмовником, комунікабельність, доступність контактів, довіра до оточення); вольові (впевненість у собі, витримка, схильність до ризику, сміливість, незалежність, стриманість, урівноваженість, рішучість, ініціативність, самостійність, самоорганізація, настирність, цілеспрямованість); організаційні (вимогливість до себе й оточення, схильність брати на себе відповідальність, уміння приймати рішення, правильно оцінювати себе та пацієнта, вміння планувати свою роботу) [6, с. 103].

Серед показників толерантної особистості майбутнього лікаря Л. Ф. Лозинська доцільно виокремлює: терпимість, поблажливість, цілеспрямованість, допитливість, рефлективність, наполегливість, piшучість, самовладання, організованість, пунктуальність, відповідальність, ініціативність, гуманність, емпатію, перцепцію, гнучкість, упевненість у собі, варіативність, самовдосконалення, свободу, почуття гумору [6, с. 103-104].

Виховна робота в медичному закладі вищої освіти - це система діяльності учасників освітнього процесу, що спрямована на пошук та впровадження нових ефективних технологій для забезпечення всебічного розвитку студентів.

Науково-педагогічною та студентською спільнотою КЗВО «Рівненська медична академія» Рівненської обласної ради було обрано проблему «Buховання толерантності та взаємоповаги учасників освітнього процесу», відповідно до якої нами було розроблено інтерактивну програму формування толерантності для майбутніх фахівців медицини та фармації.

Слід наголосити, що інтерактивні технології виховання є досить популярними в освітній сфері, оскільки використання активних форм і методів потребує інтенсивної розумової праці, причому формування особистісних якостей і характеристик стає мотивованим та ціннісним. Ефективність інтерактивних технологій полягає в тому, що освітній процес відбувається за умов постійної активної взаємодії, його учасники $є$ рівноправними, рівнозначними суб' єктами. Зауважимо, що між науково-педагогічними працівниками та студентами панують співпраця, взаємоповага і дух партнерства; визнання різноманітності учасників, їх поглядів, думок; терпимість до вірувань, уподобань, інтересів інших; відмова від домінування над іншим.

Інтерактивна програма формування толерантності охоплює інформаційні, дискусійні, проблемно-ситуативні, експресивні, тренінгові форми й методи виховання. Так, інформаційні виховні заходи проводяться у формі тематичних лекцій, презентацій, 
годин спілкування на пізнавальну тематику: «Толерантна особистість та іiі соціальна природа», «Толерантність - мистецтво співіснування людей», «Толерантність як професійно важлива якість майбутніх медичних і фармацевтичних працівників» тощо.

Дискусійними формами і засобами формування толерантності є диспути, «круглі столи», дискусійні платформи, які передбачають вироблення власної позиції, вияву критичного мислення, зважування альтернативних пропозицій і думок, прийняття обгрунтованих рішень кожним учасником дійства щодо окресленої проблеми. Питання, що виносяться на диспут («Толерантність, шляхи іiі формування 3 погляду молодої людини», «Терпіння перемагає все?...», «Толерантність і дилеми самоідентифікації медичного працівника», «Конфлікти в колективі - типове чи виключне явище?», «Гендерна та вікова чутливість і толерантність»), є неоднозначними у вирішенні та потребують саме дискусійного підходу.

Під час дискусійної платформи «Толерантність у моєму розумінні» може відбуватися діалог або полілог як комунікативна форма виховання. Рушійною силою діалогу з означеної проблеми є культура спілкування й активність слухачів. Важливе значення при цьому має емоційний стан усіх учасників, а також уміння зрозуміло висловлюватися і дослухатися до думки іншого, що сприятиме внутрішній єдності та взаємоповазі в межах групи.

Роль проблемно-ситуативних технологій у формуванні толерантності полягає у створенні в студентській групі проблемно-навчальної ситуації, яку можна реалізувати у формі рольової гри. Водночас експресивні технології додадуть досвіду розкутості та імпровізації. Такі виховні заходи передбачають наявність базових знань із визначеної теми, на основі яких за певними алгоритмами набувається первинний досвід роботи, наприклад, професійної діяльності медичної сестри, стоматолога, фармацевта. Зокрема, рольова гра «Медична сестра “очима пацієнта"» уможливлює виявити особливості комунікації за I. Харді, який окреслив типи особистості медичних сестер: «сестра-рутинер» (механічне, беземоційне виконання обов'язків); «сестра-гренадер» (рішуче, безкомпромісне виконання дій i маніпуляцій, водночас нестриманість у спілкуванні); «сестра-мама» (турботливе, співчутливе ставлення до хворих); «сестра-експерт» (відповідальне виконання окреслених обов'язків без урахування медико-деонтологічних аспектів); «сестра-непередбачуваність» (емоційно лабільне виявлення особистісних якостей, схильність до невротичних реакцій); «сестра-акторка» (усвідомлене виконання ролі медичної сестри, водночас «штучне», нещире ставлення до пацієнтів).

Дієвим інтерактивним методом визначено тренінг, в основу якого покладено методику співучасті, що виявляється в активній роботі, динамічному процесі навчання, виховання й удосконалення, під час якого відбувається вільний обмін думками, життєвим досвідом і проблемами; здійснюється спільний пошук вирішень завдань; формується тактика поведінки як у звичайних, так і нестандартних ситуаціях. Відповідно до інтерактивної програми рекомендовано такі тренінгові заняття: «Толерантність у сучасному житті», «Толерантність - складова сучасної особистості», «Толерантність - крок до гуманності».

Отже, цілеспрямоване використання інтерактивних виховних технологій активізує пізнавальну діяльність студентів, посилює особисту причетність кожного учасника освітнього процесу до формування толерантності, розвиває співробітництво, допомагає набути навичок колективної роботи.

Висновки. Отже, толерантність - це морально-етична категорія, основними принципами якої $\epsilon$ рівність, взаємоповага, доброзичливість, терпиме ставлення людини до всіх членів суспільства.

Толерантність медичного працівника - це медико-деонтологічна характеристика фахівця, що уособлює терпимість, тактовність, щирість, милосердя, здатність до компромісу, гуманний підхід до виконання професійних обов'язків. Виховний простір охоплює освітні території, де відбувається виховний вплив на формування особистості. Він забезпечує умови для актуалізації та мотивації формування толерантності здобувачів медичної освіти, впровадження в освітній процес ЗВО комплексу ефективних виховних інтерактивних технологій.

Розроблена нами інтерактивна програма формування толерантності охоплює інформаційні, дискусійні, проблемно-ситуативні, експресивні та тренінгові форми й методи виховання.

Подальшого дослідження потребує аналіз результатів упровадження інтерактивної програми формування толерантності студентів КЗВО «Рівненська медична академія» Рівненської обласної ради.

\section{СПИСОК ВИКОРИСТАНОЇ ЛІТЕРАТУРИ}

1. Аристотель. Большая этика. Сочинения : в 4-х т. / Аристотель. - М. : Мысль, 1984. - Т. 4. - 830 с.

2. Горват М. В. Генезис феномену толерантності: від філософської категорії до суспільного чинника / М. В. Горват // Вісник ЛНУ ім. Т. Шевченка. - 2012. № 22 (257). - С. 287-296.

3. Декларація принципів толерантності // Педагогіка толерантності. - 1999. - № 3-4. - С. 175-180.

4. Деленко В. Б. Дефініція «толерантності» як наукова проблема / В. Б. Деленко // Вісник Львівського університету. - 2016. - Вип. 31. - С. 28-35. - (Серія «Педагогічна»).

5. Закон України «Про вищу освіту». URL: http: // zakon 0.rada.gov.ua / laws / show / 1556-18 (дата звернення: 05.09.2019).

6. Лозинська Л. Ф. Показники толерантності особистості майбутнього лікаря / Л. Ф. Лозинська // Збірник наукових праць Хмельницького інституту соціальних технологій університету «Україна». - 2011. № 4. - С. 101-104.

7. Локк Д. Розвідка про людське розуміння : у 4-х книгах / Джон Локк ; [пер. $з$ англ. Н. Бордукова]. - Х. : Акта, 2002. - С. 152-608.

8. Сенека Л. А. Нравственные письма к Луцилию. Трагедии / Л. А. Сенека ; пер. с латин. С. Ошерова ; сост. и науч. подготовка текста М. Гаспарова ; комент. С. Ошерова и Е. Рабинович. - М. : Художественная литература, 1986. - 543 с.

9. Сучасний тлумачний словник української мови / [за заг. ред. В. В. Дубічинського]. - Х. : Школа, 2006. C. 700 .

10. Черезова М. В. Роль виховного простору в реалізації заходів із формування культури професійного спілкування майбутніх фахівців сфери туризму / М. В. Черезова // Нові технології навчання : наук.-метод. зб. - К. : Інститут інноваційних технологій і змісту освіти МОН України. - 2008. - Вип. 54. - С. 36-41.

Дата надходження до редакиії: 09.09.2019 p. 